\title{
JAZYKOVÁ STRÁNKA DISKUSÍ MLADÝCH KŘESŤANŮ V KYBERPROSTORU
}

\section{IRENA BOGOCZOVÁ, LUKÁŠ MARŠÍK}

\section{THE LINGUISTIC SIDE OF THE DISCUSSIONS OF YOUNG CHRISTIANS IN CYBERSPACE}

ABSTRACT The present article introduces the results of the analysis of texts by Czech (Catholic) Christian young adults published in 2019 and 2020 on the website signaly.cz. This page is intended to unite Christians and support them in their faith. The texts are diverse in genre, their content is purely religious or secular, but it at least remotely touches on the issues of the spiritual life of man or his/her religiosity ("soft spirituality"). Posting on the internet testifies to the need for young people not only to strengthen themselves and others in their faith in God, but also to share trivial content that relates to daily life and behind which (in the background) they see God's will, the expression of God's love and wisdom.

KEYWORDS Christianity, religiosity, religious language, religious style CONTACTirena.bogoczova@osu.cz;A15621@student.osu.cz

\footnotetext{
1 Příspěvek vznikl v rámci řešení projektu Studentské grantové soutěže Ostravské univerzity, přesněji na katedře slavistiky její Filozofické fakulty (SGSO4/FF/2019-2020), nazvaného Obraz sacrum v jazyce křest'anské mládeže, SGSO4/FF/2019-2020.
} 
„Náboženství je zapsáno lidským jazykem, musí tedy podléhat pravidli̊m lidské sémantiky. Velice se mýlí teologové, kteři tvrdí, že náboženstvíje dáno nějakým zásvětním činitelem, a proto se na ně nevztahují pravidla lidské sémantiky. Není to pravda."(Bocheński, 2001, s. 216)

\section{1 / UVEDENÍ DO PROBLEMATIKY}

Tento př́spěvek je koncipován jako teolingvistický. Teolingvistiku jako lingvistickou subdisciplínu, její počátky a vývoj, jakož i dosavadní výsledky takto zaměřeného bádání jsme představili blíže při jiné př́ležitosti, ${ }^{2}$ na tomto místě uvádíme jen to, že teolingvistiku chápeme - ve shodě s př́slušnou literaturou a zároveň značně zjednodušeně - jako vědu z pomezí lingvistiky a teologie (Kucharska-Dreiß 2004: 25), která se věnuje „zkoumání řečové činnosti zpo̊sobené (alespoň předpokládanou) prrítomností Boha: potřebou komunikace s Ním i mluvením o Něm [...], potřebou fungování jedince ve společenství věříích a struktuře církevní správy, ale také např. touhou vzdorovat a odporovat Bohu, pokusit se popř́it Jeho existenci“ (tamtéž, s. 26). ${ }^{3}$

Prakticky vzato teolingvistika má nejblíže k tradičně pojaté stylistice (popř. lexikologii) a zkoumá jazykové projevy vzniklé v „náboženské situaci“, v situaci víry (numinosity, transcendentna), během účasti na posvátnu, a to bez ohledu na její intenzitu. Řečeno ještě jinak: teolingvistika řeší otázky spojené s „náboženským využitím jazyka“ (Grzegorczykowa, 2005; Draguła, 2008). Vzhledem k tomu, že zmíněné náboženské situace a formy participace na nich jsou různé, je i „náboženský jazyk“ žánrově rozrůzněný. Použitým označením „náboženský jazyk" nemíníme specifický, předem daný a jasně vymezený druh kódu. Naopak, přikláníme se spíše k tvrzení, že se nejedná o nějaký paralelní jazyk, jazyk a priori náboženský (ZdunkiewiczJedynak, 2006, s. 39), i když (pod)vědomě cítíme, že se jisté jazykové prostředky k němu hodí více, jiné méně. Ve sféře sacrum předpokládáme vyšší kulturu vyjadřování, přítomnost biblismů a výskyt teologické terminologie - v oficiální i neformální (slangové) podobě. Proto lze náboženský jazyk nazvat sociolektem, nebot jde o útvar jisté sociální (konfesní) skupiny, jejíž členy spojuje určité přesvědčení, aktivity a dokonce instituce. Podle některých badatelů lze tento sociolekt dále dělit podle náboženského vyznání na pravoslavný, římskokatolický aj. (viz Končarević, 2012, s. 102-103).

Obdobné pochybnosti jako samotná existence „náboženského jazyka“ budí jeho „náboženská funkce“. Pokud na otázku, zda jazyk skutečně plní náboženskou funkci, odpovídáme kladně, máme na mysli náboženskou funkci konkrétního textu spojeného bezprostředně s kultem. Kromě této obřadnosti mají texty používané v komunitě věřících různé rysy a plní funkce komunikační, pojmenovávací, estetické, emocionální, reprezentační, konsolidační a jiné, které se přisuzují jazyku obecně. A budeme-li v těchto úvahách pokračovat, zjistíme, že religiózní povahu nemusí mít ani „náboženský text“ jako takový, nýbrž jisté jazykové prostředky v jeho rámci - lexémy (lexikální stylémy), anebo pouhá sémantická nástavba slov použitých v náboženském kontextu. ${ }^{4}$

2 Viz Bogoczová, I. - Černá, Z., 2020, Tištěná média pro katolickou mládež prizmatem teolingvistiky, „Studia Slavica“, XXIV/2, s. 101-119.

3 Veškeré citace $\mathrm{z}$ cizojazyčných textů jsou uvedeny v překladu autorů tohoto článku.

4 Tyto výhrady k existenci „náboženského jazyka“ najdeme již ve starších pracích z 80., 90. let 20. stol., např. Ireny Bajerowé (1988, 1994), Marzeny Makuchowské (1995) nebo Jozefa Mistríka (1992). 
Tradičně si lidé s náboženskou situací spojují vděčnost, úctu, bázeň, pokoru a na jazyk, jenž má toto vše vyjádřit, kladou vysoké nároky. Toto přesvědčení však nevypovídá o tom, jakého druhu by ony nároky měly být. Má to být požadavek na estetickou stránku textu, na spisovnost až knižnost vyjadřování, na tradici a rigidnost, na hieratičnost atd., anebo na bezprostřednost, upř́mnost, pravdivost, srozumitelnost, přesvědčivost? Dílčí analýzy jazyka náboženského hip hopu $u^{5}$ či způsobu generování textu populární Flekovy Parabible ${ }^{6}$, potvrzují závěry šetření mnoha, zejména zahraničních badatelů, že mladou generaci více oslovují výpovědi vykazující rysy běžné mluvenosti. Tím spíše, že hranice mezi rádoby vznešeným a podbízivým vyjadřováním a prázdnou žvanivostí je tenká. Prolínání profánního a sakrálního v životě člověka staví církev před rozhodnutím, na kterou stranu se přiklonit. „Na jedné straně hrozí, že se evangelium zředí, že už ho nebude možné ve světě rozpoznat. Na druhé straně ale stojí nebezpečí, že se církev stane pevnost či ghetto, a vedena strachem, aby se evangelium světem neušpinilo, se raději zavře a bude radostnou zvěst před zlým světem chránit,"vystihuje toto dilema Josef Prokeš (Prokeš 2019: 94). A nejde pouze o jazyk sdělování Dobré zprávy či pastorační činnosti, ale i o jiné obsahy, které mohou být v náboženské situaci předávány, včetně vážných, smutných či kritických. „Náboženský jazyk tedy neustále osciluje mezi nutností zachovat věrnost obsahu sdělení, včetně zachování důstojnosti hodné tohoto obsahu, a potřebou komunikativnosti a spontaneity“ a mluvit o Bohu neznamená pouze šřřit křestanství či náboženská dogmata, ale také uvést př́jemce do určitého duchovního stavu, zprostředkovat mu jistou spirituální zkušenost, umožnit mu prožít něco zvláštního, jedinečného, zvýšit jeho citlivost pro sacrum (Nowak 2005: 87).

Badatelé pozorují, že napětí mezi tradičními formami „provozování křestanství“ už mnozí duchovní řeší popnáboženstvím. Není divu, že v době, která nás nutí dělat vše online, trendy, easy a sexy, také církev podléhá tlaku spontánního „společenského konsenzu“, stejně jako mu podlehli běžní věřící. Nábožensky založení lidé prožívají, praktikují a prezentují svou víru a religiozitu stále častěji způsobem vlastním tzv. popkultuře. Nežijí v paralelním světě; události každodenní i sváteční, krásné/dobré i nehezké, veselé i tragické se odehrávají v rámci jednoho prostoru a času (Majewski - Cybulska 2017: 135, 142, 148). Popkulturizace náboženství ${ }^{7}$ vč. jeho jazykové složky je jevem přicházejícím odzdola. Konzum ve spiritualitě nutí církev řídit se zázračnou trojicí, kterou tvoři značka, obal a reklama (Lipovetsky 2007: 33, 144). Stejně jako se žáci a studenti dožadují učitele nikoli s přirozenou autoritou a hlubokými odbornými znalostmi, ale s dovedností využívat moderní technologie a co nejvíc zjednodušit vzdělávání (Zdunkiewicz-Jedynak 2010: 88), i věřící očekávají od církve trochu vědy, trochu tajemna, trochu emocí, trochu zábavy, svádění... Nehledě na to, co si myslíme o inkulturaci, aggiornamento

5 Viz Parszewska A., 2020, Religijny hip-hop na warsztacie językoznawcy, „Studia Slavica“, XXIV/2, s. 85-100; Parszewska A., Środki językowe na usługach religijnego hip-hopu, „Studia Neofilologiczne“, Częstochowa, Uniwersytet Humanistyczno-Przyrodniczy im. Jana Długosza, Częstochowa (v tisku); Bogoczová I. - Parszewska A., 2020, Parabiblia Alexandra Fleka jako sposób prezentacji treści ewangelizacyjnych, Edukacja i religia - uwikłania, konfrontacje, rozwiązania, Gdańsk, Wydawnictwo UG (v tisku).

6 Bogoczová I. - Parszewska A., 2020, Parabiblia Alexandra Fleka jako sposób prezentacji treści ewangelizacyjnych, Edukacja i religia - uwikłania, konfrontacje, rozwiazania, Gdańsk: Wydawnictwo UG (v tisku).

$7 \quad$ V souladu s definicemi pojmu popkultura je nutno i v tomto kontextu zdůraznit př́tomnost nejen její obsahové složky - myšlenek a postojů, ale i konkrétních forem jejich prezentace, favorizace a popularizace (konsenzuálnost, masovost, všudypř́tomnost, snadná dostupnost, intelektuální nenáročnost, neformálnost). 
a jiných požadavcích (post)moderní společnosti, a bez zřetele $\mathrm{k}$ tomu, zda popkulturu hodnotíme pozitivně, nebo negativně, je zřejmé, že má-li církev zaujmout, musí změnit dosavadní narativ, verbální sdělení doplnit vhodným sdělením ikonickým, zpřístupnit obsah i formu co největšímu okruhu př́jemců a zalichotit mu. „Mnohé svědčí o tom, že v době kultury obrazu tradiční formy evangelizace skrze službu slovem nepřinášejí odpovědi na otázky současného člověka způsobem, jenž je pro něj srozumitelný a uspokojivý“ (Zdunkiewicz-Jedynak 2006: 36). Ostatně je to hi-tech doba, která nás, jak píše Fabrice Hadjadj, obrátila na svou víru, nikoli naopak (Hadjadj 2016: 15).

\section{2 / ZDROJ A POVAHA JAZYKOVÉHO MATERIÁLU}

Náboženství má dnes neomezené možnosti k tomu, aby fungovalo i v kyberprostoru. ${ }^{8}$ Jak známo, tento prostor se chová jako hypertext, jenž není určen k lineárnímu čtení, ale díky četným odkazům a záložkám př́jemce sám rozhoduje o tom, co, v jakém pořadí, rozsahu či formě (psané, mluvené, verbální, ikonické) bude předmětem jeho percepce. Žánrově jsou náboženské texty na internetu značně rozrůzněné a mnohé z nich nespecifické. Část z nich slouží spíše $\mathrm{k}$ preevangelizaci než vlastnímu evangelizačnímu působení (mají zaujmout př́jemce náboženskými tématy, upozornit na př́tomnost dané církve/denominace ve společenském prostoru), anebo jsou výsledkem takovéto evangelizace či pseudoevangelizace, jsou laickou reakcí na ni. $\mathrm{Na}$ internetu je možno najít modlitby/přímluvy, svědectví víry, texty určené pro exercicie (duchovní cvičení), duchovní rozhovory, diskuze a polemiky, krátká zábavná nebo propagační videa (klipy), divácky náročnější televizní pořady, pořady pro křestanské děti, přenosy (záznamy) bohoslužeb či koncertů.

Pro potřeby tohoto článku jsme využili duchovní blogy, přesněji řečeno příspěvky a diskuze mladých věřících na českém komunitním webovém portálu signaly.cz ${ }^{9}$, jehož hlavním cílem je sdružovat věřící mládež v online prostoru a podporovat ji ve víře. Vzhledem k tematické orientaci tohoto webového portálu se na něm objevují př́ispěvky, v nichž autoři neskrývají svou religiozitu, konfesní afiliaci, soudržnost s komunitou věříích. Drtivá většina př́ispěvků na tomto webu je autorizována (účet uživatele je ověřitelný podle jeho totožnosti), přispěvovatelé mají svou profilovou fotografii a vystupují bud' pod svým občanským jménem, nebo pod různými přezdívkami (tzv. nicky, napr. Hippy, IM-POSSIBLE, Irelevantní, Krasnazena, Neposeda, Suposlav, Sancika, Teretzin). Na zmíněném portálu se nachází několik dílčích blogů přístupných veřejnosti, ${ }^{10}$ jejichž vlastníci publikují své texty (tyto př́spěvky mohou být v rámci blogu zařazeny do

8 Reflexe této skutečnosti není nijak nová. Již na konci r. 1996 se ve Frankfurtu nad Mohanem konala první mezinárodní konference o možnostech využívání internetu pro křestanské účely (I European Christian Internet Conference).

9 Web signaly.cz vznikl již v roce 2001 jako nástěnka akcí Sekce pro mládež České biskupské konference $\mathrm{a} v$ průběhu let procházel různými transformacemi. Jeho fungování v současné komunitní podobě založené na blozích bylo zahájeno na Celostátním setkání mládeže v Táboře dne 13. srpna 2007, tedy ještě v době, kdy v České republice nebyla známa celosvětová sociální sít Facebook. Portál začal nabízet mladým věřícím prostor pro vlastní tvorbu, diskuzi, sdílení a vzdělávání a všechny tyto funkce si zachovává až do současnosti.

10 Např. Aaginčin blog uživatelky jménem Aaginka; Dary jsou i v maličkostech všedních dnů uživatelky Zuzankie; Ferencưv zápisník uživatele Ference; Grafofiliov blog uživatelky jménem Katusi; (I)relevantně uživatelky Irelevantní; Jen tak zlehka uživatele Hippy; Lidožroutka glosuje uživatelky Krasnazena; MISSION IM-POSSIBLE 
tematických rubrik/sekcí, které si autor blogu sám vytvořil). K analýze jsme vybrali celkem 91 př́spěvků od 41 autorů, které byly publikovány v letech 2019 a 2020. Volba př́spěvkủ byla vcelku nahodilá - využili jsme př́spěvky, které byly v uvedeném období dostupné a které se alespoň částečně týkaly duchovního života. Ze stejného důvodu nebyly do našeho materiálu začleněny př́spěvky, v nichž autoři popisovali banální zážitky ze svého každodenního života a které se netýkaly spirituálních témat. ${ }^{11}$ Př́klady (slova, úryvky textů) z př́spěvků uvádíme v původní podobě, neprovádíme žádnou jejich jazykovou ani ediční korekci.

Obecně lze konstatovat, že $\mathrm{z}$ hlediska publikování př́ispěvků $\mathrm{v}$ rámci výše uvedeného křestanského komunitního portálu jsou výrazně aktivnější dívky (ženy) než chlapci (muži). V souboru př́spěvků ze všech navštívených blogů se nachází 63 textů od děvčat/žen ${ }^{12}$ a 28 textů, jejichž autory jsou mladí muži. ${ }^{13}$ Kritérium pohlaví pro nás sice nebylo primární, jeho zohlednění se však ukázalo jako signifikantní při diferenciaci tematického zaměření př́spěvků, $\mathrm{k}$ čemuž se podrobněji vyjádříme níže. Na tomto místě stojí za zmínku fakt, že zatímco dívky a mladé ženy běžně popisují situace všedního života nebo se svěřují s intimními tématy, u věřících mužů pozorujeme tendenci podělit se úvahami na závažnější témata, která se týkají aktuálního společenského dění, a z reálných událostí odvozují nějaká nadčasová ponaučení. ${ }^{14}$

S ohledem na velmi omezenou př́tomnost jiných identifikačních údajů, které byly odvoditelné pouze nepř́mo - vyplynuly z kontextu (např̀. věk nebo místo bydliště), ${ }^{15}$ nebyly brány $\mathrm{v}$ potaz žádné další proměnné. Na základě těchto nepř́mých ukazatelů (mnozí z autorů a autorek pravidelně zasazují své př́běhy do moravských a slezských regionů - Brněnsko, Valašsko, Haná, Slovácko, Těšínsko) však můžeme konstatovat, že převážná část mládeže aktivní na

uživatelky IM-POSSIBLE; Míša píše... uživatelky Heiduška; Magdin blog uživatelky Meruňka; Mezi soby uživatelky Jordanna; Moje úvahy o životě uživatele jménem Igor; Opus supo - zážitky hanáckého konópka uživatele Suposlava; Písmenko k písmenku uživatelky Leňouš; Terezka si píše uživatelky Teretzin; Vrabcakblog:) uživatelky $Z$ dendanda; $Z$ Andrejčina denícku uživatelky Neposeda; Život nenaplánuješ uživatelky Sancika; blog s názvem תיב The Blog of Beth תב̌ivatelky Elizabětka; blog společenství Exkluzivně (nejen) z klauzury apod. Mezi přispěvateli jsou tedy mladí lidé - ženy i muži; někdy je jméno-přezdívka zavádějící, ale při určování pohlaví autora př́spěvku se řídíme také tvarem l-ového př́čestí a adjektiva, popř. jinými signály.

11 Nutno dodat, že i takové př́spěvky se na jednotlivých blozích v rámci křestanského komunitního portálu signaly.cz vyskytují, avšak vzhledem ke křestanskému zaměření webu nejsou nijak časté (srov. př́spěvek Darování vlasů na blogu Lásky jedné tmavovlásky uživatelky Merit, publikovaný 5. ř́jna 2020, v němž autorka popisuje, jak si nechala ostř́hat své dlouhé vlasy a rozhodla se je darovat na výrobu paruky, a ke stejnému činu povzbuzuje ostatní dívky).

12 Jedná se o texty 32 autorek: Aaginka, Ano9, BarčaQ, Danka-Štěpánka, Dáška-el, Elizabětka, Heiduška, IM-POSSIBLE, Irelevantní, Jankac, Jordanna, Julinka, Kamila Rajtarová, Katusi, Klotylda, Kollenka, Krasnazena, Leňouš, LuKoty, Majkiki, MariettaND, Meruňka, Neposeda, Odetta, Oqoq, Sancika, Slu-nicko, Teretzin, Terez14, Tkaničkauboty, Zdendanda, Zuzankie.

13 Jedná se o texty 9 autorů: Dage, Ferenc, Hans von Liechtenstein, Hippy, Igor, Inigo, Jenda, MartinM, Suposlav. 14 Povahu důvěrné zpovědi mají přispěvky o rozhodnutích pro řeholní život. Této problematice jsou věnovány především př́spěvky na komunitním blogu Exkluzivně (nejen) z klauzury, který byl vytvořen virtuálním společenstvím se stejným názvem, kde publikuje více autorek.

15 Věk je na profilu uživatele položkou, u níž si může uživatel nastavit různé stupně ochrany soukromí. Tento údaj tak byl veřejně zpřistupněn pouze u některých autorů. U dalších bylo možné věk odhadnout díky různým indiciím (podle fotografie nebo $\mathrm{z}$ obsahu textu). Zjištujeme, že v převážné většině př́ipadů na blogy přispívají teenageři a dospělí uživatelé mladšího věku (do 35 let). Tímto věkovým vymezením se řídili i autoři tohoto článku, přesto je třeba podotknout, že do souboru zkoumaných př́spěvků mohl být výjimečně zařazen i text napsaný starší osobou. 
tomto českém křestanském portálu žije ve východní části republiky, popř. z ní alespoň pochází. ${ }^{16}$ Např́lklad název blogu Opus supo-zážitky hanáckého konópka uživatele jménem Suposlav ukazuje na původ autora z oblasti Hané; také autorka Danka-Štěpánka ve svých příspěvcích nepřímo odkazuje na svůj valašský původ (srov. Jsme obyčejná katolicky vychovávaná rodina, vyrůstající ve valašském prostředîin); rovněž z textů uživatelky Majkiki lze odvodit její př́islušnost k nějakému moravskému regionu (srov. $Z$ kuchyně orientované na východ $v$ dálce vidíme Hostýn $[. . .]^{18}$ ). Rozsah jednotlivých příspěvků na blozích se obvykle pohyboval v rozmezí jedné až dvou stran formátu $\mathrm{A} 4,^{19}$ jejich návštěvnost - v desítkách až stovkách tzv. zhlédnutí.

\section{3 / TEMATICKÉ ZAMĚŘENÍ PŘÍSPĚVKŮ}

Pokud jde o tematické zaměření zveřejňovaných článků, je třeba zdůraznit, že i v rámci náboženské tematiky tvoří pestrou mozaiku. Základním tématem byl vzhledem k aktuální pandemii virus COVID-19. Byl námětem pro celý př́spěvek, anebo rezonoval nějakým zpơsobem ve sdělení jiného obsahu. ${ }^{20}$ Názvy viru a opatření proti němu se odrazily i v pokusech blogerů o humor, používání neoficiálních pojmenování či dokonce ve vlastní jazykové kreativitě, což je veselejší stránka této neštastné situace, do které se lidé dostali (srov. čínský dárek světu ${ }^{21}$ jako metaforické a ironické vyjádření skutečnosti, že virus se k nám dostal z čínského Wu-chanu; slovo koronapárty ${ }^{22}$ jako název pro sešlost, kde se lidé nakazili koronavirem; slovo koronakrize ${ }^{23}$ pro označení specifické krize zapříčiněné virem COVID-19; konstrukce povinnost nosit náhubek ${ }^{24}$ jako synonymum pro plošné nařízení zakrývat si ústa a nos; sloveso rouškovat ${ }^{25}$ znamenající totéž co ,šít roušky'; sloveso covidět²6 ve významu,být nakažený koronavirem, být nemocný na

16 Toto zjištění koresponduje s geografickým zastoupením věřících $\mathrm{v}$ české společnosti - moravské regiony jsou, jak známo, v rámci České republiky tradičně katoličtější.

17 Př́spěvek Jak mé rozhodnutí brali sourozenci? uživatelky Danka-Štěpánka na blogu společenství Exkluzivně (nejen) z klauzury, publikovaný 27. dubna 2020.

18 Př́spěvek Město plné zabijáků a nebo námět do bijákư? uživatelky Majkiki na blogu Chci poezii, publikovaný 28 . dubna 2020.

19 Tento rozsah jednotlivých př́spěvků byl zjištěn pomocí jejich překopírování do programu Word obvykle se pohyboval v rozmezí $2-4,5$ tis. znaků při rádkování 1,5. Kratší, nebo naopak delší příspěvky se na blozích vyskytují také, byt jsou v menšině.

20 Téma epidemie viru COVID-19 se objevilo nebo bylo nějakým způsobem zmíněno v $19 \mathrm{z} 91$ analyzovaných př́spěvků napsaných v r. 2020.

21 Příspěvek Jakjsme žehnali pole z pohodlí domova uživatele Suposlav na blogu Opus supo-zážitky hanáckého konópka, publikovaný 25 . dubna 2020.

22 Př́spěvek Bez roušky a na chatě dát pivní kúru uživatele Hans von Liechtenstein na blogu Kaněc filma, publikovaný 6. řijna 2020.

23 Př́spěvek Co pro mě znamenal nouzový stav nařzený vládou ČR ze strachu z pandemie COVID-19v r. 2020 uživatele MartinM, publikovaný 2 . září 2020.

24 Příspěvek Jakjsmežehnali pole z pohodlí domova uživatele Suposlav na blogu Opus supo-zážitky hanáckého konópka, publikovaný 25 . dubna 2020.

25 Příspěvek Jak být frikulín $v$ době koronavirové uživatelky Katusi na blogu Grafofilův blog, publikovaný 3. dubna 2020.

26 Příspěvek Co-vid-išs? Neco-vid-ím. Snad. uživatelky Irelevantní na blogu (I)relevantně, publikovaný 13. zář́i 2020. 
COVID-19“ apod.). Ryze „covidový“ je např. obsah př́spěvku Kdo je tady Spasitel?. ${ }^{27}$ Náboženský rozměr př́spěvků je patrný z tendence vidět př́činu šiřrení viru v Boží vůli, což potvrzuje zmíněné propojení profánního se sakrálním: to, co se děje tady a ted', je nějakým způsobem řízeno vyšší silou, je výsledkem dosavadního chování lidí, trestem nebo lekcí, kterou nám uštědřil Bůh, ale také novou šancí vést bohulibější život. $V$ této souvislosti uvádíme okazionalismus: hříchonavirus (Pocítil jsem na své duši akutní př́znaky pozitivního nálezu celosvětové epidemie hř́chonaviru; ${ }^{28}$ Hřichonavirus mě opět promořil a s hanbou vyhlížím další zpověd'29).

Dalším vážným tématem př́spěvků byl Černobyl. Oživení zájmu o jadernou katastrofu v Černobylu v roce 1986 vyvolal stejnojmenný miniseriál natočený v koprodukci HBO a Sky a vysílaný v první polovině roku 2019. Zmíněným tématem se zcela obírá př́spěvek Čest hrdinům $z$ Černobylu, ${ }^{30}$ který vznikl z pohnutek připomenout sebeobětování likvidátorů jaderné katastrofy.

Samostatný tematický okruh je spojen se smrtí a umíráním, což je téma, které je v moderní společnosti tabuizováno (např. př́spěvky O smrti smrt'oucí... ${ }^{31}$; Porodní asistentka u lưžka umírajicího ${ }^{32}$ ). Autoři se nevyhýbají vzpomínkám na své zemřelé blízké, např. na kněze (příspěvek $C D$ bible, kněz a cesta autem.... ${ }^{33}$ ), na bratrance (příspěvek Vzpomínky ${ }^{34}$ ), na dobrou známou (příspěvek Paní Anežka $\left.a^{35}\right)$. V textech zaznívá téma zdraví; mezi př́spěvky se objevují žádosti o př́mluvu, modlitbu (např. př́spěvek Prosba o modlitbu $u^{36}$, v němž autorka nejdřív popisuje čtenářum svůj komplikovaný zdravotní stav; naopak př́spěvek Modlitby v nemocij7 má univerzální platnost a nabízí příklady modliteb, které čtenáři mohou využít v době nemoci).

Reakce na aktuální dění v české společnosti se odrážejí ve speciální sekci sledovaného komunitního portálu nazvané Přímluvy. Zde mladí věřící zveřejňují své modlitby a ostatní uživatelé se $\mathrm{k}$ nim mohou připojit. Vhodným př́lkladem je př́mluva uživatele jménem Marmik zveřejněná 11. srpna 2020 v reakci na srážku dvou vlaků u Českého Brodu, ke které došlo 14. července 2020 a při níž tragicky zahynul jeden ze strojvedoucích:

Modleme se za zahynulého strojviodce Martina (40 let, pohřben je v Ústí nad Orlicí) i zraněné cestujicí při srážce vlaků u Českého Brodu, ke které došlo za stmívání 14. července na nejlépe zabezpečené trati shodou několika nepř́znivých okolností.

Autorem další přímluvy zveřejněné 9. června 2020 v návaznosti na záplavy, které začátkem léta postihly oblast Šumperska a Uničovska, je uživatel Tofl:

27 Př́spěvek uživatele Suposlav na blogu Opus supo - zážitky hanáckého konópka, publikovaný 15. března 2020.

28 Př́spěvek Př́běh jedné zpovědi uživatele Suposlav, publikovaný 24. června 2020.

29 Příspěvek Př́běh jedné zpovědi uživatele Suposlav, publikovaný 24. června 2020.

30 Př́spěvek uživatelky Dáška-el na blogu Kdyžcestu nevidím, jdu s di̛věrou, publikovaný 13. června 2019.

31 Př́spěvek uživatelky IM-POSSIBLE na blogu MISSION IM-POSSIBLE, publikovaný 26 . února 2020.

32 Př́spěvek na blogu společenství Exkluzivně (nejen) z klauzury, publikovaný 19. března 2020.

33 Příspěvek uživatelky Leňouš na blogu Písmenko k písmenku, publikovaný 4. února 2020.

34 Př́spěvek uživatelky Slu-nicko na blogu Pořád na cestě, publikovaný 20. září 2020.

35 Př́spěvek uživatelky Heiduška na blogu Míša pišse..., publikovaný 7. května 2020.

36 Př́spěvek uživatelky Sancika na blogu Život nenaplánuješ, publikovaný 8. února 2020.

37 Př́spěvek uživatelky Sancika na blogu Život nenaplánuješ, publikovaný 18. července 2020. 
Prosím o modlitbu za všechny postižené záplavami (Uničovsko a Šumpersko) a za následujicí dny, týdny a měsíce, které budou z hlediska dešt'u náročné.

Jinak lze konstatovat, že se na blozích řeší běžné události odehrávající se v životě mladého člověka, potažmo mladého křestana / mladé křestanky.

\section{4 / POKUS O ŽÁNROVOU TYPOLOGII}

Vzhledem k tomu, že blogy nejsou zřejmě spravovány primárně s ohledem na žánrovou sourodost textů, provést genologickou typologii př́ispěvků je nelehký úkol. Nicméně na tuto charakteristiku materiálu není nutno zcela rezignovat, tím spíše, že jsou v něm zastoupeny minimálně dva druhy přispěvků: takové, které jsou založeny na deskripci, bez výrazné fabulace, a ty, které tíhnou $\mathrm{k}$ epice. Jde tedy o vzpomínky (nepravidelné deníkové záznamy), zážitky z cest, kritické zhodnocení konkrétní situace. Již dříve jsme zmínili jistý podíl úvahových textů. Některé texty vznikly primárně jako výzvy, apely, jiné mají formu dopisu (včetně oslovení); objevují se básnické útvary, texty mající povahu rady, návodu (receptu), inspirace a povzbuzení ke konkrétní činnosti.

Kritické posouzení přináší příspěvek Ve frontě na zpověd', ${ }^{38} \mathrm{v}$ němž autor popisuje chování osob čekajících na svátost smíření. Stejné svátosti se týká i př́ispěvek Př̌běh jedné zpovědi ${ }^{39}$ popisující události nastalé v den autorovy zpovědi. Rozladěnost je patrná v př́ispěvku Studentská ${ }^{40}$, v němž se autorka vyjadřuje k tomu, jak jí v době karanténních opatření chybí studentské mše. Téma karantény se objevuje i v textu Př́běh o kočičkách ${ }^{41}$, v líčení duchovního života rodiny jedné blogerky během netypického velikonočního týdne na jaře roku 2020. Vhodným př́lkladem je i příspěvek Boží humor ${ }^{42}$, v němž autorka popisuje př́hodu, jež je výsledkem neuvěřitelné shody „náhod“, za kterou vidí Boží prozřetelnost a Jeho smysl pro humor. Popisné povahy jsou dále texty nazvané Můj křest ${ }^{43}$, Drsná zkušenost... ${ }^{44}$ (tou zkušeností je míněn pokus o sebevraždu v případě autorčiny kamarádky) a Lekce pokory ${ }^{45}$ (autorka popisuje přehlíživé chování zdravotnického personálu vưči pacientce během ošetření popáleniny, zároveň tyto útrapy přirovnává $\mathrm{k}$ utrpení svatého Heřmana, který nemoc pokorně snášel). V těchto líčeních konkrétních událostí je často akcentována osobní zkušenost autora s vírou - událost přináší duchovní prožitek, je svědectvím Božího vedení, přítomnosti „vyšší síly“, Boží moudrosti. Současně tyto příběhy obsahují jakési poselství pro ostatní (radu, inspiraci, povzbuzení, útěchu, návod, jak v obdobných situacích postupovat) a tato doporučení mají mnohdy velmi konkrétní podobu. Např. v příspěvku Jak

Příspěvek uživatele Hippy, publikovaný 20. října 2019. 
být frikulín ${ }^{46} v$ době koronavirové ${ }^{47}$ radí autorka čtenářům, jak zůstat trendy i během pandemie. Na druhé straně zde máme „mužský“ přistup k tématu: autor příspěvku Největši šance našeho života ${ }^{48}$ upozorňuje na šanci pro lidstvo, které se díky epidemii mưže výrazně přibližit Bohu.

Jak už bylo naznačeno, příspěvky mají v ojedinělých případech formu dopisu. Takovým př́padem je př́spěvek Milá karanténo... ${ }^{49}$, v němž autorka touto formou komunikuje na téma duchovního života po zavedení karanténních opatření proti šíření koronavirové nákazy. Příjemcem jiného dopisu (př́ispěvek Díky ${ }^{50}$ ) je Bůh a obsah textu je veskrze děkovný.

Povahu rozhovoru má př́spěvek Jak mé rozhodnutí brali sourozenci?, ${ }^{51} \mathrm{v}$ němž autorka pokládá svým sourozencům otázky a zjištuje, jakým způsobem je ovlivnilo její rozhodnutí vstoupit do kláštera ${ }^{52}$.

Nechybí samozřejmě ani úvahy a různá osobní zamyšlení (srov. př́ispěvek Je těžké být introvertem? $\left.{ }^{33}\right)$. Příspěvek Cesta učedníka $a^{54}$ je pokusem o typologii křestanů; příspěvek Dát svưj život?! !55 $^{5}$ je úvahou o tom, co všechno může člověk darovat Bohu; př́spěvek Výkonnostní modlitby a pýcha $a^{56}$ se týká smyslu častého, ale bezmyšlenkovitého modlení; příspěvek Postní předsevzetít ${ }^{57}$ se zabývá prospěšností volby postních předsevzetí; v př́spěvku Senegalské úvahy ${ }^{58}$ dochází ke srovnání křestanů s muslimy a současně také života v bohaté Evropě s životem v chudé africké zemi. Autorka textu Vim, co nechci ${ }^{59}$ zrovna ukončila studium na střední škole a přemýšlí o své budoucnosti. Př́spěvek O utrpení ${ }^{60}$ je úvahou na téma, proč Bůh nechává člověka trpět.

Na blozích se objevují také cestopisné „fejetony“ a různé dílčí postřehy z cest (srov. Kazachstán: cesta tam a zase zpátky; ${ }^{61}$ Moje svatojakubská pout' (Camino de Santiago);;2 Mnišský „erasmus “63). Jak již bylo zmíněno, blogy nabízejí výjimečně poezii. K veršovaným skladbám patří básně:

46 Výraz frikulín je slangovým slovem, které bylo složeno z anglických slov free, cool a in. V jazyce české mládeže označuje člověka, jehož životní styl se dá charakterizovat právě výše uvedenými anglickými výrazy (Jílková 2004: 110-111).

47 Přispěvek uživatelky Katusi na blogu Grafofilův blog, publikovaný 3. dubna 2020.

48 Př́spěvek uživatele Hans von Liechtenstein na blogu Kaněc filma, publikovaný 15. dubna 2020.

49 Přispěvek uživatelky Leňouš, publikovaný 2 . dubna 2020.

50 Př́spěvek uživatelky MariettaND, publikovaný 2 . února 2020.

51 Stejné problematiky se týká př́íspěvek Jak se pozná povolání k zasvěcenému životu? uživatelky Danka-Štěpánka na blogu společenství Exkluzivně (nejen) z klauzury, publikovaný 27. dubna 2020.

52 Př́spěvek na blogu společenství Exkluzivně (nejen) z klauzury, publikovaný 6. srpna 2020.

53 Př́śspěvek uživatele Hans von Liechtenstein na blogu Kaněc filma, publikovaný 21 . května 2020.

54 Př́spěvek uživatele Hippy na blogu Jen tak zlehka, publikovaný 20. září 2020.

55 Příspěvek uživatelky IM-POSSIBLE na blogu MISSION IM-POSSIBLE, publikovaný 6. června 2020.

56 Př́spěvek uživatele Dage na blogu Ex duris gloria, publikovaný 6. září 2019.

57 Př́spěvek uživatele Ferenc na blogu Ferencưv zápisník, publikovaný 28. února 2020.

58 Př́spěvek uživatele Hippy na blogu Jen tak zlehka, publikovaný 14. března 2020.

59 Př́spěvek uživatelky Odetta na blogu Draco dormiens nunquam titillandus - Odettin blog, publikovaný 31. července 2019.

60 Př́spěvek uživatele Hippy na blogu Jen tak zlehka, publikovaný 5. řína 2020.

61 Příspěvek uživatelky Jordanna na blogu Mezi soby, publikovaný 28. března 2020.

62 Př́spěvek uživatele Teretzin, publikovaný 5. srpna 2020.

63 Př́spěvek uživatele Suposlav na blogu Opus supo - zážitky hanáckého konópka, publikovaný 7. března 2020. 
Utíkánít ${ }^{64}$ - vypovídá o tom, jak člověka dohánějí chyby z minulosti; Holka, měla bys ${ }^{65}$ - ličí nátlak na autorku ze strany jejího okolí, jež ji nabádá k vdavkám; Půjdu a naučím se hrát na klavír ${ }^{66}$ - je prosbou adresovanou Bohu a souvisí s lidskými chybami; Zklamaná $a^{67}$ - vyjadřuje zklamání způsobené blízkým člověkem; a o zradě a rozčarování je báseň Vstřebáváníín .

Ojediněle se vyskytl příspěvek v podobě receptu (Povidlíl $\left.{ }^{69}\right)$.

\section{5 / VÝSLEDKY PRÁCE S JAZYKOVÝM MATERIÁLEM}

\section{1 / Personifikované a verbalizované sacrum}

$\mathrm{V}$ tomto oddíle př́ispěvku se zaměříme na konkrétní jazykové prostředky, jimiž blogeři vyjadřují svůj vztah k Bohu, Kristu, svatým. Ty pak zprostředkovávají představy mladých křestanů o tom, jak „funguje“ Bůh v jejich představách. Jsou odrazem toho, co sami od Boha očekávají, jsou obrazem jich samotných. Do textů se promítají známá zjištění, že si člověk Boha polidštuje, připisuje mu vlastnosti, které ze své podstaty mít nemůže; že je těžké přemýšlet v lidských dimenzích o Bohu a zároveň se oprostit od stereotypů, od tzv. karikatur (Lachmanová 2014) či démonických obrazů Boha (Frielingsdorf 1992, 1995).

Vedle tradičně užívaných přímých i nepřímých pojmenování Boha (Pán Bůh, Pán, Hospodin, Otec, Bůh Otec, Trojjediný), ${ }^{70}$ Ježíše Krista (Kristus, Spasitel, Syn Boží, Vykupitel, Ježǐšsk, Betlémské dítě, Nebeský Ženich nebo pouze Ženich) a Panny Marie (Matka Boží, Bohorodička, Krásná Paní nebo Neposkvrněná) se v př́spěvcích objevují různá modifikovaná a originální pojmenování. Srov.:

(Bůh) primár̆ Nebeského oddělení (např. [...] tam v náručí primáře Nebeského oddělení už ho nic nebolí, ani tělo ani duše [...] $\left.]^{11}\right)$;

(Ježíš) Boží miminko (např. Svatý Josefje známý jako patron št'astné smrti. Směle jsem si ho adoptovala i jako patrona ochrany života. Přece jen věřm i tomu, že pomáhal, jak uměl, u Ježišškova porodu a nejednou tomu Božímu miminku zachránil život. ${ }^{72}$

Z pravopisného hlediska je nutno zdůraznit, že velkými písmeny jsou důsledně psána nejen plná slovní pojmenování (Pán Bůh, Ježíš Kristus a Panna Maria), ale v převážné většině případů také zájmena On, Mu, vưči Němu, Ho, pro Něj, s Ním apod. (srov.: Kdyžjsme s Ním každý den, tak

64 Př́spěvek uživatelky Heiduška na blogu Míša píše..., publikovaný 4. ř́jina 2020.

65 Příspěvek uživatelky Heiduška na blogu Míša pišse..., publikovaný 26. září 2020.

66 Příspěvek uživatelky Klotylda, publikovaný 9. června 2019.

67 Př́spěvek uživatelky Aaginka na blogu Aaginčin BLOG, publikovaný 27. listopadu 2019.

68 Př́spěvek uživatelky Heiduška na blogu Míša píše..., publikovaný 16. července 2020.

69 Př́spěvek uživatelky Ano9 na blogu Tady a ted', publikovaný 3. září 2020.

70 Dlužno dodat, že přivlastňovací adjektivum Boží je použito jak v prepozici (Boží hlas, Boží humor, Boži království, Boži láska, Boží lék, Boží milosrdenství, Boží milost, Boži moudrost, Boží nabídka, Boží povolání, Boží plán, Boži prostředek, Boží přikázání, Boži přtomnost, Boží slovo, Božísrdce, Boží volání, v Božích rukou, zvolání Svatá Boží Dobroto!), tak - v souladu se zvyklostí - v postpozici (do rukou Božích, dům Boží, Matka Boží, oslava Boží, sláva Boží, slovo Boží, Syn Boží, s pomocí Božî).

71 Příspěvek O smrti smrt'oucí... uživatelky IM-POSSIBLE na blogu MISSION IM-POSSIBLE, publikovaný 26. února 2020.

72 Příspěvek Porodní asistentka u lůžka umirrajicího na blogu společenství Exkluzivně (nejen) z klauzury, publikovaný 19. března 2020. 
Ho začneme poznávat a začneme rozeznávat Jeho hlas; $;^{73}$ Bưh na rozdíl od lidí se však neurazí, On počitá i s našimi chabými pokusy... ; $^{74}$ Děkuji Bohu, že jsem došla až sem, že jsem to v̌̌echno zvládla a že dá-li On, blýská se mi na lepší časy ;5 Čím víc jsem s Ním, tím lépe poznávám Jeho hlas.;6 [...] přestože žiji jako samostatný jedinec, tak $s$ Nim nejsem jistě nikdy samotnýy7). Zájmena s malým počátečním písmenem jsme zaznamenali jen výjimečně a s velkou pravděpodobností se jednalo o nedopatření ze strany autora, o čemž svědčí přítomnost majuskule u téhož slovního druhu na jiných místech textu (např. Občas na Boha křič́m, občas s ním nedokážu mluvit; ${ }^{78}$ Aby müj den ř́dil On. A zároveň musím být připraven s ním spolupracovat ${ }^{79}$ ).

Zpravidla blogeři $\mathrm{k}$ Bohu přistupují fatalisticky, jako $\mathrm{k}$ vyšší síle, a v dobrém úmyslu se mu odevzdávají do péče (např. V tom kritickém bodě se mě totiž dotkl Bưh a změnil směr celého mého života ${ }^{80}$ ). Úcta k Bohu (svatým), pokora a bázeň před Ním či důvěra k Němu jsou konfrontovány $\mathrm{s}$ jinými postoji. Patři k nim přistup založený na vzájemné rivalitě, jako by se člověk mohl Bohu vyrovnat, postavit se $\mathrm{Mu}$, vzdorovat $\mathrm{Mu}$, dát $\mathrm{Mu}$ za vyučenou. Srov.:

Prošel jsem o víkendu takovým lehčŕm soubojem s Bohem; ${ }^{81}$

Občas na Boha křičim, občas s ním nedokážu mluvit, občas se mi zdá hluchý a slepý [...];:82

Přli ǐščasto se mi stává, žes Bohem nejdřív nekomunikuji (nemodlím se nebo se modlím špatně), pak mu přestávám úplně rozumět a jsem na jiné vlně. Z nedorozumění vzejde to, že ho začnu tak nějak více nebo méně vědomě obviňovat z riozných negativ v mém životě. ${ }^{83}$

Základem jiného postoje je iluze partnerství (rovnosti) ve vztahu mezi člověkem a Bohem, vzájemné kooperace, synergie, nap̌r. :

Někde jsem četl dobrý př̀měr - je to jako šlapat na kole - jeden pedál sešlápnu já, druhý Bưh, a tak pořád dokola, a to kolo se potom fakt rozjede, ${ }^{84}$

Je mi skoro 30 a pořád nevím, kam mě vlastně Pán zve. Ale když se podívám zpětně, tak vím, že od té doby, co se Ho na to ptám, mě každý den někam posouvá. ${ }^{85}$

$\mathrm{Z}$ některých formulací nabýváme dojmu, že relace mezi člověkem a Bohem funguje díky shovívavému postoji Boha vi̊či (nedokonalým) lidem a jedinečnému Božímu smyslu pro humor, srov.:

73 Příspěvek Modlitební komưrka uživatele Hippy na blogu Jen tak zlehka, publikovaný 27. září 2020.

74 Př́spěvek Dát svioj život? uživatelky IM-POSSIBLE na blogu MISSION IM-POSSIBLE, publikovaný 6. června 2020.

75 Př́spěvek Prosba o modlitbu uživatelky Sancika na blogu Život nenaplánuješ, publikovaný 8 . února 2020.

76 Př́spěvek Slyšet Boží hlas chce čas uživatele Dage na blogu Ex duris gloria, publikovaný 20. srpna 2020.

77 Př́spěvek Co pro mě znamenal nouzový stav nařízený vládou ČR ze strachu z pandemie Covid-19 v r. 2020 uživatele MartinM, publikovaný 2 . září 2020.

78 Př́spěvek Jak to jen zvládáte? uživatelky Zdendanda na blogu Vrabcakblog:), publikovaný 23. září 2020.

79 Př́spěvek Ráno je základ uživatele Dage na blogu Ex duris gloria, publikovaný 12. června 2019.

80 Př́spěvek Parabola uživatelky Kamila Rajtarová, publikovaný 4. dubna 2019.

81 Př́spěvek O utrpení uživatele Hippy na blogu Jen tak zlehka, publikovaný 10. ř́jjna 2020.

82 Př́spěvek Jak to jen zvládáte? uživatelky Zdendanda na blogu Vrabcakblog:), publikovaný 23. září 2020.

83 Př́spěvek Nedostatek komunikace vede k neprátelství uživatele Dage na blogu Ex duris gloria, publikovaný 12. května 2019.

84 Př́spěvek Ráno je základ uživatele Dage na blogu Ex duris gloria, publikovaný 12. června 2019.

85 Př́spěvek Jeden bod uživatelky Kamila Rajtarová, publikovaný 13. května 2020. 
Boží humor, pokud mě zrovna nedokáže naštvat, je někdy kouzelný a nepřekonatelný:). ${ }^{86}$

Výše zmíněné škádlivé až kritické postoje nepozorujeme ve vztahu ani k Ježíši, ani k ostatním svatým. Plyne to zřejmě ze skutečnosti, že v nich mladí křestané nevidí potenciální hrozbu, zdroj trestu, nebezpečí všudypřítomné kontroly a důrazu „na výkon“, jak je tomu v př́padě Všemohoucího. Tito „ostatní svatí“ jsou jaksi neškodní. Jejich př́itomnost dodává lesku, zdobí, zkrášluje; jejich úkolem je člověku pomáhat, ochránit jej, inspirovat ho. Srov.:

(svatý Jakub) [...] pozdravit to krásné místo, svatého Jakuba i prátele; ${ }^{87}$

(svatá Barbora, svatá Kateřina) Ale měla jsem si vybrat biřmovací jméno. Když jsem pročítala životopisy světic, zaujaly mě dva detaily: U svaté Barbory, že zemřela rukou vlastního otce. U svaté Kateřiny, že byla krásná a zároveň chytrá; ${ }^{88}$

(svatý Heřman) Při úterní ne dvakrát milé návštěvě popáleninového centra jsem na hlavního hrdinu sv. Heřmana v duchu vzpomínala, jak snášel veškeréústrky, necitlivéjednání a dokázal prijímat i takové věci, jako treba to, že se sám kvuili své nemoci nenají, neumyje; ;9 $^{89}$

(svatý Antonín) Není žádným tajemstvím, že naše rodina „spolupracuje se svatými. Co jen se nám třeba takový svatý Antonín nahledal ztracených věcí. A o tom, jak jsme díky př́mluvám svatého Josefa k dobrému bydlení přišli, užjsem také psala; ${ }^{\circ}$

(svatý Josef) Svatý Josefje známýjako patron št'astné smrti. Smèle jsem si ho adoptovala ijako patrona ochrany života. Přece jen věřim i tomu, že pomáhal, jak uměl, u Ježišsova porodu a nejednou tomu Božimu miminku zachránil život; ${ }^{91}$

(svatý Patrik) A tak začala moje pout' do země proslavené svatým Patrikem a kapelou U2 - do Irska;92

(svatý Filip Neri) Jako patrona jsme malému vybrali svatého Filipa Neriho, kterému se říká „št'astný svatý“.93

\section{2 / Ostatní způsoby verbalizace sacrum}

Díky bližšímu seznámení s formální stránkou textů jsme zaznamenali několik zvláštností, které bychom nyní rádi prezentovali. Soustředíme se pouze na formální (výstavbovou) stránku textu na způsob jeho generování, zvolené jazykové prostředky apod. Bytostní opozice sacrum × profanum zde nehraje roli.

V názvech (titulcích, nadpisech) příspěvků převažují slovní spojení nominální povahy (Poslední rok, Ve frontě na zpověd', Drsná zkušenost..., Můj křest, Paní Anežka, Tlustá Alžbětka a Panna Ma-

86 Příspěvek Boží humor uživatelky Leňouš na blogu Písmenko k písmenku, publikovaný 16. února 2020.

87 Př́spěvek Moje svatojakubská pout' (Camino de Santiago) uživatelky Teretzin, publikovaný 5. srpna 2020.

88 Př́spěvek Můj křest uživatelky Kollenka, publikovaný 23 . května 2020.

89 Př́spěvek Lekce pokory uživatelky Zuzankie na blogu Dary jsou v maličkostech všedních dnů, publikovaný 29. července 2020.

90 Přispěvek Štěpánka uživatelky Zdendanda na blogu Vrabcakblog:), publikovaný 24. června 2020.

91 Příspěvek Porodní asistentka u lǔžka umirrajicího na blogu společenství Exkluzivně (nejen) z klauzury, publikovaný 19. března 2020.

92 Př́spěvek Mnišský „erasmus“ uživatele Suposlav na blogu Opus supo-zážitky hanáckého konópka, publikovaný 8. března 2020.

93 Př́spěvek Křtiny poprvé a podruhé uživatelky LuKoty, publikovaný 19. září 2020. 
ria, O smrti smrtoucí, Postní předsevzetí, Senegalské úvahy, Cesta učedníka, Největši šance našeho života, Jeden bod, Boží humor, Lekce pokory, O kličcovém významu nenápadných věcí, Vytunelované Velikonoce, Porodní asistentka u li̊̌žka umírajícího), méně časté jsou jednoslovné názvy (Štěpánka, Partyzán, Teror, Bahnícko, Parabola, Povidlí, Studentská). Podobu věty mají názvy: Bellisima sorellina... aneb Máj, (je) lásky čas!; Neumřu normální; Jakjsme žehnali pole z pohodlí domova; Ničím se nezneklidňuj, ničím se netrap; Nastav své srdce... prijímám i za Tebe... Bůh (je) na poličce; Ráno je základ; Nedostatek komunikace vede kneprátelství; Všechno zléje kněčemu dobré; Žádná tajná př́sada neexistuje, výjimečně se objevilo krátké souvětí: Vím, co nechci). Některé větné titulní formulace mají formu otázky (Kdo je tady Spasitel?; Jak se pozná povolání k zasvěcenému životu?; Je těžké být introvertem?; Jak mé rozhodnutí brali sourozenci?). Dlužno doplnit, že názvy př́spěvků v drtivé většině př́ípadů korespondují s jejich obsahem, vystihují pointu; výjimkou je již výše zmiňovaná báseň Půjdu a nauč́m se hrát na klavír, u níž zůstává motivace volby nadpisu skryta.

V samotných př́ispěvcích se kromě neutrální slovní zásoby objevuje také tradiční lexikum spojené s křestanskou věroukou a církevním prostředím (adorace, archanděl, Bible, biřmování, biřmovací jméno, bohoslužba, Boží milosrdenství, Boži přikázání, diecéze, evangelium, fara, farník, farnost, hostie, hřich, chrám, kázání, klášter, kněz, kř̌̌ž, popř. křižzek na čelo, křǐžek na krku, křížová cesta, křest, křtiny, misie, mše svatá, náboženství, ohlášky, oltár̆, pan farář, postní doba, postní předsevzetí, pout', pozdravení pokoje, roráty, růženec, řeholní život, schóla, svatá zpověd', svaté prijímání, svátost, svatostánek, víra, zpovědnice, žehnání apod.). Někteří autoři ve svých příspěvcích používají také speciální (zpravidla teologické nebo religionistické) pojmosloví, které nemusí být pro běžného věřícího srozumitelné (např. benedikce, breviár̆, duchovní formace, eucharistie, evangelizace, exercicie, juniorát, kanovník a kanovnice, klauzura, kongregace, kontemplativní modlitba, konvertita, numerár̆, noviciát, (hnutí) Opus Dei, penitent, sestra formátorka). Objevují se také názvy reálií, které se týkají jiné denominace než římskokatolické a které mohou patřit do slovní zásoby kohokoli, bez ohledu na jeho religiozitu (např. Korán, muslimové, protestanti, Strážní věž, Svědci Jehovovi, zlepšit si karmu).

Časté je použivání expresivních, hovorových nebo jednoznačně nespisovných jazykových prostředků. V převážné většině případů se týkají banálních témat, profánní sféry života (bitkař, kolaudačka, pajdák ,pedagogická fakulta', pracák, rochnit se, rychlokvaška, správňácký kluk, šlamastyka, špindíra, t'ululum, být $v$ cajku apod.). V souvislosti se sférou sacrum jsou takovéto výrazy použivány sice zřídka, ale přece (srov. synátor pro označení Božího Syna, Ježíše Krista: Bůh Otec nám dal svého synátora ${ }^{94}$ ). Nechybí ani slova slangová (např. být out, fejk, frikulín, mega fandit, storícko, šméčko, ublog\{nutí), včetně běžného neoficiálního názvu Společenství mladých věříích - spolčo/Spolčo. Přítomnost anglicismů potvrzuje obecnou zálibu mladé generace v těchto prostředcích a neformálním způsobu vyjadřování (srov. Dokonce jsem se později zúčastnil moravských hodů a pozval je na večer. Awesome; ;5 bro (brother) Bruno; opravdu nejvíc reálně freaky creepy beznadějný scénár̆ [...]; ;' Následovala další cesta na tentýž úr̆ad a definitivní chill out staré občanky; ${ }^{97}$

94 Příspěvek $A$ „sakra“já ty Vánoce na... uživatelky Leňouš, publikovaný 23. prosince 2019.

95 Příspěvek Je těžké být introvertem? uživatele Hans von Liechtenstein na blogu Kaněc filma, publikovaný 21. května 2020.

96 Příspěvek Čest hrdinům z Černobylu uživatelky Dáška-el, publikovaný 13. června 2019.

97 Příspěvek Neumřu normální... uživatele Suposlav, publikovaný 25. června 2020. 
Nikdy bych nevěrila, že výuka náboženství může být tak lovely; ${ }^{98}$ meetingy a firemní eventy; on-line mše svatá; off-line režim; Předem zdravím všechny trolly, co se budou chtít rýpat ve slovíckách [...]; ${ }^{99}$ very funny story; Zapomeňte na to, že jste vlastně odborník na hokej/migrační politiku/domácí politiku/fotbal/whatever ${ }^{100}$ apod.).

V analyzovaných textech jsme narazili i na vulgarismy a nadávky (blbec, dřit hubou o zem, na plnou hubu, naprdlý, administrativní průser, sakra, sviňa, stará babka, vyžrat; vzdát se trưnu, klenoti̊ a katedrál a začit, uždoprdelekonečně, vidět Krista tam, kde skutečně prebývá $\left.{ }^{101}\right)$. Ojediněle jsou vulgární slova napsaná s hvězdičkou nahrazující vynechané písmeno, což má zmírnit negativní stylový př́iznak slova (na*raně). Na druhé straně je patrná snaha zjemnit, „učesat“ projev (srov. psí výtrus, podělaná situace). Běžným jevem (zřejmě záměrným stylémem) je používání jazykových prostředků z jiných funkčních stylů a tvoření netradičních slovních spojení:

Jako by Bůh byl opravdu ten pověstný automat na ochranu a požehnání, ${ }^{102}$

Když se o vás lidé začnou dozvídat, že jdete do kláštera, začnete být takovým googlem. Pořád se vás někdo na něco ptá, ${ }^{103}$

Zatím jsem Biblické nemluvně, teprve začinám, ale už ted' je to krásné a moc se těším na každou chvilku s Písmem; ${ }^{104}$

$V$ mládí jsem zažila teror kostelní, byl takový nenápadný, ale maminka byla vytrvalá, ${ }^{105}$

To jsem si uvědomil i ve vztahu ke své modlitební šñưre [,sled modliteb']. Bylo mi líto jí přerušit; ${ }^{106}$

Sestry, nevěsty zasvěcené Kristu [,řeholnice, jeptišky'], se těší na setkání se svým Ženichem; ${ }^{107}$ Od té doby jsem mèla čest doprovodit na druhou stranu už možná víc jak čtyři sta pacientů (ne, nedělám v hospici...tam jsem strávila jen krátkou - avšak velmi krásnou - epizodu mojí praxe) a násobně více pacientům jsem oznámila, že na Nebeském oddělení [,v nebi, v místě, pobývání duše člověka po smrti'] na ně už brzy čekajĭ, ${ }^{108}$

Bylo by smutné, kdyby se naplnily jen chrámy konzumu a naše církevní chrámy i v době velikonoční dál mrtvě zely prázdnotou. ${ }^{109}$

98 Př́spěvek „Takže když budu hodný, tak budu pak nesmrtelný?" uživatelky Dáška-el, publikovaný 7. zář́i 2020.

99 Př́spěvek „Takže když budu hodný, tak budu pak nesmrtelný?““ uživatelky Dáška-el, publikovaný 7. zář́i 2020.

100 Příspěvek Jak být frikulín v době koronavirové uživatelky Katusi na blogu Grafofiliov blog, publikovaný 3. dubna 2020.

101 Př́spěvek Tož já vám to teda řeknu uživatelky Terez14 na blogu Šufl, publikovaný 25. září 2019.

102 Př́spěvek Cesta učedníka uživatele Hippy na blogu Jen tak zlehka, publikovaný 20 . září 2020.

103 Př́spěvek A co na to Vaši? uživatelky Julinka na blogu společenství Exkluzivně (nejen) z klauzury, publikovaný 26 . června 2020.

104 Př́spěvek Učédnictví uživatelky Ano9 na blogu Tady a ted', publikovaný 6. června 2020.

105 Př́spěvek Teror uživatelky Krasnazena na blogu Lidožroutka glosuje, publikovaný 30 . ledna 2020.

106 Př́spěvek Výkonnostní modlitby a pýcha uživatele Dage na blogu Ex duris gloria, publikovaný 6. září 2019.

107 Příspěvek Porodní asistentka u lǔžka umirajicího na blogu Exkluzivně (nejen) z klauzury, publikovaný 19. března 2020.

108 Příspěvek O smrti smrt'oucí... uživatelky IM-POSSIBLE na blogu MISSION IM-POSSIBLE, publikovaný 26. února 2020.

109 Př́spěvek Vytunelované Velikonoce uživatelky Meruňka na blogu Magdin blog, publikovaný 25. dubna 2020. 
Kromě uvedených jsme narazili na formulaci přední česká mariánská ctitelka jako sebeironické označení pro obdivovatelku Panny Marie, spojující slovo „přední“, související spíše se světskou slávou, a tradiční náboženský obrat „mariánský ctitel“, nebo pobožnostní běh ve významu,běh k místům, kde se lidé obvykle modlí‘, srov.:

rozhodla jsem se dnes jako přední česká mariánská ctitelka k pobožnostnímu běhu. A to k obnovené kapličce [...]). ${ }^{110}$

Do kategorie nespisovných prostředků patří prvky obecné češtiny (bylo to hrozný, důležitý je vědět, je to fakt těžký, každej den, prej, různý věci, šílenej rok, studetský léta, špatný zkušenosti, vejprask, vejš$k a$, vysokej požadavek, úspěch byl vydřenej apod.), jakož i prostředky moravských dialektů (změnila sas, dotklo sa mňa to, vypořádat sa s tím; pro mn̆a, s tebů, moja sestra, ani náhodů, beru to jako velků zradu; částice tož - v podobě tož i toš: tož já vám to teda řeknu, toš slovo dalo slovo; lexém napučený ve smyslu ,uražený' (v nářeční podobě spíše „napučaný“): byla jsem napučená.

V přítomnosti následujících slovních spojení spatřujeme autorský záměr: obsahují lexikální jednotky v jistém smyslu protikladné, protimluvné. Přestože jsou značně nesourodá, zdůrazňují kontrast mezi svatým a profánním, mezi podstatným a nepodstatným a jsou výsledkem vědomé snahy ozvláštnit přispěvek, zvýšit jeho „uměleckou hodnotu“:

kláštery paneláki̊: Jsme uzavřeni v klášterech paneláků, bytovek a rodinných domư:;11 poutnický přetlak: jak asi řeši poutnický přetlak a udržují stav lidí uvniťr na státem povolených 30; ${ }^{112}$

rochnit se ve suým bahnitým rybnícku: Ježíš neumřel za to, abych se dál rochnila ve svým malým bahnitým rybnícku a v̌̌ecko kolem sebe zamořovala. ${ }^{113}$

Jak jsme už zmínili, blogeři se vyjadřují častokrát na velmi vážná témata, není divu, že cítí potřebu zmírnit obsah sdělení. Přeneseně (opisně, eufemisticky) pojmenovávají smrt, a to bud' pomocí tradičních formulací spojených se sférou sacrum:

sestřicka smrt (I když to někde hluboko asi už tušite, nikdo vám jako studentům na medicině „,na plnou hubu“ neřekne, že uzdravování lidí je z velké části hlavně o umírání. A tak se „sestřička smrt" stane vaší věrnou a výkonnou spolupracovnicí [...]; ${ }^{.114}$

předešel nás do nebe (... na kterého v těchto dnech vzpomináme, protože nás předešel do nebe), ${ }^{115}$

110 Příspěvek Tlustá Alžbětka a Panna Maria uživatelky Irelevantní na blogu (I)relevantně, publikovaný 1. května 2020.

111 Př́spěvek Největši šance našeho života uživatele Hans von Liechtenstein na blogu Kaněc filma, publikovaný 15. dubna 2020.

112 Př́spěvek Kdo je tady Spasitel? uživatele Suposlav na blogu Opus supo-zážitky hanáckého konópka, publikovaný 15 . března 2020.

113 Př́spěvek Bahnícko uživatelky Kamila Rajtarová na blogu Kama taky píše blog, publikovaný 11. dubna 2020.

114 Př́spěvek O smrti smrtoucí... uživatele IM-POSSIBLE na blogu MISSION IM-POSSIBLE, publikovaný 26. února 2020.

115 Př́spěvek CD bible, kněz a cesta autem... uživatelky Leňouš na blogu Písmenko k písmenku, publikovaný 4. února 2020. 
anebo jednoduše, „prozaicky“, např.: \$1

netluče mu srdícko (vzápětí se z úst lékaře dovídáte, že už mu netluče srdičcko). ${ }^{116}$

$\mathrm{V}$ textech nepřekvapuje př́tomnost biblismů, i když jejich frekvence není nijak velká. Jde např. o slovo hřivna, přesněji modifikaci frazeologizmu „zakopat hřivnu“ (A trochu se bojím, že ta kontemplativní modlitba je hřivnou, pro nižjsem úspěšně vykopal díru a užji jen uložit a zahrabat $\left.{ }^{117}\right)$. Biblického původu jsou také slovní spojení lámání chleba (A tak, když dojde na „lámání chleba“ [...] ${ }^{118}$ ); nést (svioj) kř́ž ([...] být s nimi, když nesou svůj kř̌ž [...] $]^{119}$; Když tak nad tím přmemýš́m, tak utrpení a nesení nějakého kř̌že mi dává smysl, jen pokud existuje Bưh... ${ }^{120}$ ); zvednutý prst Boží (Viděli v nich výstražně zvednutý prst Boží, upozorňující je na to, že dęlají něco špatněr121); starozákonní pýcha předchází pád (A takjsem dopadla, jakjsem dopadla. Pýcha předchází pád $\left.{ }^{122}\right)$; Nesud'te, abyste nebyli souzeni Mt 7, 1 ([...] kolik je takových zoufalých lidí kolem nás a o kterých nevíme, pro které je těžká tíha života neúnosná a jou a sáhnou si na život... Nesud'te, abyste nebyli souzeni $\left.{ }^{123}\right)$. Dalšími prŕiklady jsou celé pasáže z Nového zákona, dokonce formálně označené jako citát:

[...] „Když se však modlíš ty, vejdi do své komůrky, zavři dveře a modli se k svému Otci, který je ve skrytosti, a tvůj Otec, který vidí i to, co je skryté, ti odplatí. "Mt 6, 6;:;4

Tito tři muži se tehdy postavili do obrovské jaderné trhliny - mezi nás, kteři žijeme dnes a kteř́ bychom nebýt toho možná ani nežili, a mezi smrtící radiaci [...] „Nikdo nemá větší lásku než ten, kdo položí život za své prátele. "Jan 15, 13; ${ }^{125}$

Otázek jsou spousty, odpovědi žádné, nebo neuspokojivé (třeba taková pozitivní z listu Jakubova: „Prosíte, a nic nedostáváte, protože prosíte špatně”:)) [List] Jakubưv 4, 3;126

[...] poslední dobou razím heslo mého oblíbeného Jakuba: Modlete se jeden za druhého, abyste byli uzdraveni. Velkou moc má vroucí modlitba spravedlivého [List] Jakubưv 5, 16; ;17

Hodně mě taky zaujalo, že protestanté se uči nazpamět některé úryvky z Písma. To chci zkusit. Zatím jsem Biblické nemluvně, teprve začinám, ale už ted' je to krásné a moc se těším na každou

116 Př́spěvek Jak to jen zvládáte? uživatelky Zdendanda na blogu Vrabcakblog:), publikovaný 23. září 2020.

117 Př́spěvek Partyzán uživatele Suposlav na blogu Opus supo - zážitky hanáckého konópka, publikovaný 26. května 2020.

118 Př́spěvek Čest hrdinům z Černobylu uživatelky Dáška-el, publikovaný 13. června 2019.

119 Př́spěvek Porodní asistentka u lůžka umírajícího na blogu Exkluzivně (nejen) z klauzury, publikovaný 19. března 2020.

120 Př́spěvek Modlitby v nemoci uživatelky Sancika na blogu Život nenaplánuješ, publikovaný 18. července 2020.

121 Příspěvek Nejdưležitějěš věc při koronavirových opatřeních chybí uživatele Igor na blogu Moje úvahy o životě, publikovaný 12. ř́jina 2020.

122 Př́spěvek Jeden bod uživatelky Kamila Rajtarová, publikovaný 13. května 2020.

123 Příspěvek Drsná zkušenost... uživatelky Leňouš na blogu Písmenko k písmenku, publikovaný 19. června 2020.

124 Př́spěvek Modlitební komůrka uživatele Hippy na blogu Jen tak zlehka, publikovaný 27. září 2020.

125 Př́spěvek Čest hrdinům z Černobylu uživatelky Dáška-el, publikovaný 13. června 2019.

126 Př́spěvek Jak to jen zvládáte? uživatelky Zdendanda na blogu Vrabcakblog:), publikovaný 23. září 2020.

127 Příspěvek Boží humor uživatelky Leňouš na blogu Písmenko k písmenku, publikovaný 16. února 2020. 
chvilku s Písmem. Tuhle jsem objevila poklad, který si ted' často opakuju - „Jako si Otec zamiloval mně, tak jsem si já zamiloval vás... Zưstaňte v mé lásce. "Jan 15, 9. ${ }^{128}$

Kromě citátů $\mathrm{z}$ bible se $\mathrm{v}$ textech mladých autorů objevily výroky významných církevních autorit - papežů, kardinálů, např.: \$1

Zưstaneš tu jen ty, Bože, a já. Jak jsi to chtèl, když jsem pres všechny náboženské akce na tebe nemèl čas. „Pán nám daroval mnoho slunečných dnů a jemného vánku, dny bohatých úlovků. Byly ale rovněž chvíle rozbouřených vod a protivětru, jak tomu bývá $v$ dějinách církve, $k d y$ se zdá, že Pán spí. Vždy jsem ale vědèl, že v této lod'ce je Pán a že lod'ka církve není moje, není naše, nýbrž jeho. A Pán ji nenechá klesnout ke dnu. "Benedikt XVI. ${ }^{129}$

Moc se mi líbí slova kardinála Vlka: „Advent a Vánoce znamenají, že Ježíš přišel, aby s námi zůstával ve všech /našich/ situacích“. A ráda mu z hloubi duše dávám za pravdu. ${ }^{130}$

Závěrem vzpomeňme přítomnost vlastních jmen $\mathrm{v}$ analyzovaných textech. O jménech Boha a svatých jsme se již zmínili, nicméně v životě věříích je důležitá i návštěva poutních míst. Proto v textech nepřekvapují toponyma, jako např. španělské Santiago de Compostela, Fatima v Portugalsku, Lurdy ve Francii či Čenstochová v Polsku, ale i Křtiny na Brněnsku, Hostýn na Kroměřǐžsku aj. Další skupinu tvoří názvy spojené s církevním kalendářem, i když případné malé písmeno umožňuje následující „názvy“ hodnotit také jako metaforická vyjádření. Ve významu ,neděle' se objevilo ustálené sousloví den Páně; následují názvy křestanských svátků: Popeleční středa, Květná nedēle, Velký pátek, Velikonoční triduum, svátek Panny Marie Sedmibolestné, svátek Nejsvětější Trojice, svátek sv. Marka, čtvrtá neděle adventní. V projevu mladých lidí zní poněkud nezvykle zlidovělý (zprofanovaný?) obrat Anno Domini - léta Páně, typický pro křestanské historické prameny a znamenající rok po narození Krista (,našeho letopočtu ${ }^{\mathfrak{\iota}_{131}}$, zde ve významu,v roce'), např. Narodila jsem se léta Páně 1997 ve svátečním okruhu V̌̌ech svatých a památky věrných zemřelých, ${ }^{132}$ Večer před čtvrtou nedělí adventní léta Páně 2004 mi volal kamarád. ${ }^{133}$

\section{6 / SHRNUTÍ}

Náboženství kopíruje lidské uvažování, promlouvá ústy člověka a obrací se k člověku, je tedy artikulováno lidským jazykem. Ten se pohybuje mezi hieratičností a běžnou mluveností. Kromě teologických termínů či biblismů (z nichž se mnohé staly součástí ryze laických výpovědí) neexistují zvláštní „klíčová slova“ náboženského textu, stejně jako neexistuje žádný jeho univerzální vzorec. Autory posuzovaných příspěvků na internetu jsou věřící z řad laiků, mladí lidé žijící obyčejné životy. Jejich př́spěvky svědčí o potřebě jakési každodenní „měkké spirituality“ (Štampach 2000), jakož i o potřebě ji sdílet. Záliba ve vyumělkovaném, estetizujícím či archaizujícím projevu se na pozadí celkového jazykového materiálu jeví jako marginální. Převažuje

128 Př́spěvek Učednictví uživatelky Ano9 na blogu Tady a ted', publikovaný 6. června 2020.

129 Př́spěvek Největši šance našeho života uživatele Hans von Liechtenstein na blogu Kaněc filma, publikovaný 15. dubna 2020.

130 Př́spěvek A „sakra“ já ty Vánoce na... uživatelky Leňouš, publikovaný 23. prosince 2019. Citovaný úryvek $\mathrm{z}$ př́spěvku autorky byl upraven.

131 Dostupné z: https://cs.wikipedia.org/wiki/Anno_Domini (cit. 10. 12. 2020).

132 Př́spěvek Tožjá vám to teda řeknu uživatelky Terez14, publikovaný 25. září 2019.

133 Př́spěvek Můj krest uživatelky Kollenka, publikovaný 23. května 2020. 
věcnost, jednoduchost, někdy až překvapivá přímočarost. Jsou používány běžné jazykové prostředky i narativní postupy. Autoři propojují profánní se sakrálním nejen se záměrem dosáhnout komického efektu nebo se s Bohem nějak „skamarádit“, ale hlavně proto, že v aktuálních událostech vidí nějaký hlubší smysl, Boží všudypřítomnost.

\section{THE LINGUISTIC SIDE OF THE DISCUSSIONS OF YOUNG CHRISTIANS IN CYBERSPACE}

SUMMARY The purpose of the article was to analyze the language means used in texts on spiritual topics. The authors of the analyzed texts are young Christians, Catholics from the Czech Republic, who publish their thoughts by means of the website signaly.cz. A total of 91 texts of 41 more or less regular contributors were analyzed. The texts are very different in genre and theme, but they are united by a certain degree of spirituality. It has been found out that linguistic material contains a wide range of means - from literary to bookish (including archaisms, lexical biblisms) through neutral to commonly spoken (including vulgarisms, slangisms, non-literary and non-adapted anglicisms). This result confirms the thesis that there is no distinct biblical language (biblical style) and that religious texts range between sacred reverence and common secular spokenness.

\section{LITERATURA}

I Bajerowa I., 1988, Rola języka we współczesnym polskim życiu religijnym, O języku religijnym. Zagadnienia wybrane, red. M. Karpluk, J. Sambor, Lublin, s. 9-20.

I Bajerowa I., 1994, Swoistość języka religijnego i niektóre problemy jego skuteczności, „Łódzkie Studia Teologiczne“, 3, s. 11-17.

I Bocheński J., 2001, Mezi logikou a vírou. Rozhovor s Józefem Bocheńským vede Jan Parys, překlad J. Ogrocký, Brno.

I Bogoczová I. - Černá Z., 2020, Tištěná média pro katolickou mládež prizmatem teolingvistiky, ,Studia Slavica“, XXIV/2, s. 101-119.

I Draguła A., 2008, Transgresja języka - o Bogu po świecku. Na podstawie wybranych tekstów młodzieżowych, Język katechezy, red. R. Przybylska, W. Przyczyna, Seria Teolingwistyka, 5, Tarnów, s. 213-223.

I Frielingsdorf K., 1995, Falešné predstavy o Bohu (jejich vnik, odhalení a překonání) [Dämonische Gottesbilder, 1992], překlad. A. Sirovátková, Kostelní Vydří.

I Grzegorczykowa R., 2005, Wypowiedzi religijne jako forma uczestniczenia w sacrum, Język religijny dawniej i dziś II, red. S. Mikołajczak, T. Węcławski, Poznań, s. 15-24.

I Hadjadj F., 2016, Jak dnes mluvit o Bohu? Evangelizační anti-pomůcka, překlad P. Doležalová, Brno.

I Chládková V. - Michálek E. 1970, K otázce biblismů v českých spisech J. A. Komenského, "Slovo a slovesnost", 4, s. 325-336.

I Jílková L., 2004, Víte, kdo to je frikulín?, „Naše řeč“, 2, s. 110-111. 
I Кончаревић К., 2012, Норме вербалног комуникацийског понашања у православном социолекту српског и руског језика, Теолингвистика (Международный тематический сборник статей), ред. А. К. Гадомский, К. Кончаревић, Београд, s. 102-115.

I Kucharska-Dreiß E., 2004, Teolingwistyka - próba popularyzacji terminu, Język religijny dawniej i dziś I, red. S. Mikołajczak, T. Węcławski, Poznań, s. 23-30.

I Lachmanová K., 2014, Karikatury Boha, Kostelní Vydří.

I Lipovetsky G., 2007, Paradoxní štěstí. Esej o hyperkonzumní společnosti, překlad M. Pokorný, Praha.

I Majewski J. - Cybulska P., 2017, Narodziny popreligii. Religia w dobie kultury popularnej, „Sensus Historicae“, XXVIII/3, s. 135-149.

I Makuchowska M., 1995, Styl religijny, Przewodnik po stylistyce polskiej, red. S. Gajda, Opole, s. 449-473.

I Mistrík J., 1992, Religióny štýl, „Stylistyka“, s. 82-89.

I Nowak M. D., 2005, Świadectwo religijne, Gatunek-jezzyk-styl, Lublin.

I Parszewska A., 2020. Religijny hip-hop na warsztacie językoznawcy, „Studia Slavica“, XXIV/2, s. 85-100.

I Prokeš J., 2019. Pán se stará, Praha.

I Štampach I. O., 2000, A nahoře nic... O možnostech postmoderního člověka žít duchovně, Praha.

I Zdunkiewicz-Jedynak D., 2006, Surfujac po Internecie w poszukiwaniu Boga... Gatunki komunikacji religijnej na polskich katolickich stronach internetowych, Tarnów.

I Zdunkiewicz-Jedynak D., 2010. Jak mówić o Bogu językiem współczesnego świata? O dylematach inkulturacji w języku polskiego Kościoła, „Studia Salvatoriana Polonica“, 4, s. 87-97. 